\title{
Which businesses actually help the global poor?
}

Article · March 2013

DOI: $10.1108 / 20454451311303284$

CITATIONS

5

2 authors, including:

\section{Amir Pezeshkan}

University of Baltimore

16 PUBLICATIONS 69 CITATIONS

SEE PROFILE
READS

87 


\title{
Which businesses actually help the global poor?
}

\author{
Adam Smith and Amir Pezeshkan \\ Old Dominion University, Norfolk, Virginia, USA
}

Abstract

Purpose - This paper suggests that BoP producer businesses provide greater potential positive impact on poverty alleviation than $\mathrm{BoP}$ consumer businesses. With this purpose, the authors explore the positive short-term and long-term economic effects of BoP producer businesses on the poor and compare these effects with those from BoP consumer businesses.

Design/methodology/approach - The paper applies several economic and organizational theories to $\mathrm{BoP}$ businesses to shed light on the value each creates for the poor.

Findings - It is argued that BoP producer businesses create more economic value for the poor by providing these societies with access to markets, capital and capabilities, and organizational advantages they currently lack.

Practical implications - Implications for the poor, businesses considering opportunities at the BoP, and future research are discussed.

Originality/value - With the help of economic theories, this paper describes the ways in which access to markets, well-established organizations, and technology help remedy poverty. This paper also contributes to the $\mathrm{BoP}$ literature by focusing upon $\mathrm{BoP}$ producer businesses. By comparing $\mathrm{BoP}$ consumer and producer businesses, the authors highlight several advantages of production at the BoP. Keywords Base of the Pyramid, Poverty alleviation, Technology transfer, Developing countries, Economic growth

Paper type Research paper

\section{Introduction}

When Procter and Gamble "sells a sachet of detergent or an individual disposable diaper to a Base of the Pyramid (BoP) consumer in Mexico or India [...] the poor consumer has simply substituted buying the detergent or the diaper for rice or beans or some other essential product" (Davidson, 2009, p. 28). The $\$ 15-\$ 22$ a month earned by fulltime workers in Project Shakti (Unilever, 2005), a program that encourages women to be entrepreneurs by distributing Unilever's products to rural areas in India, is not substantially bettering their incomes or lifting them out of desperate poverty. Yet BoP businesses have often been acclaimed by scholars and practitioners in the management community as viable alternatives to government and aid-based programs for alleviating global poverty (Prahalad and Hart, 2002; Prahalad, 2005; London and Hart, 2004). Significant multinational (MNC) resources have been mobilized by the vision that doing business with the poor can create profits for corporations and end global poverty in its present form by reaching a vast underdeveloped market consisting of the world's poorest people. These initiatives are most often designed to access markets of the global poor that have between 600 million and four billion people, depending on whether the cutoff for inclusion in the BoP market is $\$ 6$ a day or much lower (Pitta et al., 2008).

BoP research has often focussed on designing for and selling products to the poor in creative and cost-effective ways from a strategic management perspective. Hence, the focus in the BoP literature is on business models that can better serve them (London and Hart, 2004; Simanis and Hart, 2009) and product adaptation/innovation to meet
Received 30 March 2012 Revised 23 June 2012 8 August 2012 18 September 2012 9 October 2012 Accepted 10 October 2012

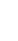


SAJGBR

2,1

44 their consumption needs (Anderson and Markides, 2007; Subrahmanyan and Gomez-Arias, 2008; Viswanathan et al., 2011). Despite this current overwhelming emphasis on consumers (Ramachandran et al., 2012) that links markets at the BoP to products that were not previously available there, BoP businesses can also serve another critical objective: transferring BoP-produced goods or services to wealthier markets. This is referred to as the BoP producer approach (Rangan et al., 2007; London, 2007; Ramachandran et al., 2012). Unfortunately, the BoP literature has generally been vague in distinguishing between the two orientations, despite the fact that they are substantially different business models with significantly different poverty alleviation pathways. Hence, a clear analysis of how each of these types of businesses will improve the lives of the poor has been neglected.

With this gap in mind, we seek to extend the understanding of the poverty alleviation mechanisms of $\mathrm{BoP}$ producer businesses recently suggested by Ramachandran et al. (2012), which include access to markets, access to knowledge and innovation rich ecosystems and access to organizations. In doing so, we begin informing and discussing two questions on which there is not enough focus in the BoP literature: how do base of the pyramid $(\mathrm{BoP})$ businesses improve the lives of the global poor? And which businesses create the most value for the poor, BoP producer or BoP consumer? Thus, our paper discusses both the consumer and producer orientation and their differences from a poverty alleviation perspective, which has received comparatively little attention because $\mathrm{BoP}$ literature is dominated by strategic management scholars.

Our work highlights the advantages of the producer perspective. Successful emerging economies like Asian Tigers and China provide evidence that rapidly increasing GDP per capita through increased productive capacity is possible in a post-industrialized world (Lall, 1992; etc.). The challenge is to set up humane manufacturing and other productive facilities at the BoP. Increased standards of living through industrialization and manufacturing should not be accompanied by abuses of workers' human rights. Although this approach requires a greater commitment from firms than the commonly used BoP consumer model (Prahalad and Hart, 2002; etc.), the stakes are still just as high for the global poor, who often live short, harsh and uncertain lives with a goal of mere survival. Therefore, business models that seek to operate at the $\mathrm{BoP}$ should have an idea of the impact that their proposed business model will have on these populations. In fulfilling this objective, this paper lays groundwork for understanding the economic impacts that both consumer and producer models can have and suggests that viewing the global poor as producers is a better way to help lift them out of poverty (Karnani, 2007).

This paper is organized in three sections. First, we will briefly review some of the major arguments in BoP research. In particular, we outline the most prominent criticism related to $\mathrm{BoP}$ that selling to the poor does not help them. This provides impetus for an increased examination of $\mathrm{BoP}$ producer businesses. To highlight the potential benefits of producer businesses, we utilize Ramachandran et al.'s (2012) work which has focussed upon: access to product markets, access to factor markets and factors of production, access to knowledge rich ecosystems which offer the poor access to new technology and the ability to innovate and finally access to organizations. We compare the economic benefits generated by BoP producer businesses and $\mathrm{BoP}$ consumer businesses across these categories in order to develop some propositions. We conclude by offering directions for future research and also discuss limitations of our work. 
Theory and propositions

Central focus of the BoP research

The concept of the bottom (or base) of the pyramid was first introduced by Prahalad and Hart (2002). They described the $\mathrm{BoP}$ as a potential market of approximately four billion consumers for MNCs and advocated that these MNCs could sell to the poor to meet their needs, raise their incomes by employing them in the distribution of goods and services and involve them in the global marketplace for the first time. Since then, scholars have attempted to understand the BoP environment and articulate solutions for businesses.

A wide array of studies have focussed upon offering advice and proposing strategies, products and business models for prospective and ongoing businesses based on the conditions and situations of BoP markets (London and Hart, 2004; Simanis and Hart, 2009; London et al., 2010; Anderson and Markides, 2007; Subrahmanyan and Gomez-Arias, 2008). For example, London and Hart (2004) identified social embeddedness, collaboration with nontraditional partners, co-inventing custom solutions and generating local capacity as critical success factors for businesses in BoP markets. Anderson and Markides (2007) explored how companies can serve BoP consumers and proposed that efficient means for serving the poor would be achieved by leveraging acceptability, affordability, availability and awareness. London et al. (2010), based upon longitudinal data of $18 \mathrm{BoP}$ initiatives, highlighted the R\&D models that were best suited for new market entry, conceptualizing business model development in terms of architectural and component R\&D.

Relatively fewer studies have emphasized the poverty alleviation aspect of $\mathrm{BoP}$ businesses. For example, Prahalad and Hammond (2002) asserted that MNCs could improve the living condition of the poor by encouraging commerce in the BoP markets. They described products, which MNCs would provide to these settings that could decrease living costs for the poor and help raise standards of living. A recent study argued that entrepreneurship, under the right circumstances, could help decrease social exclusion. They explained how connecting tourism entrepreneurship to local innovation could provide entrepreneurs with local knowledge and sources on which they could construct their local supply chain. Nakata and Weidner (2012) asserted that certain aspects of new product characteristics, social context dynamics and marketing environment factors can counter different aspects of poverty (e.g. economic deprivation, physical deprivation, psychological deprivation and knowledge deprivation) and enhance product adaptation in BoP markets. Hahn (2009) examined the current benefits to the poor of increased consumption with costs of future possible environmental degradation, applying a Rawlsian system of justice, in which concerns for future generations must be balanced with concerns for the present one.

\section{Criticisms of the BoP approach}

Although there are contributions that $\mathrm{BoP}$ consumer businesses can make to the poor, which include meeting needs with innovative goods and services, incorporating the poor in the global market, providing jobs in distribution, supply chains and "retail" and lowering prices of goods that the poor can use since they currently pay relatively more (Prahalad and Hammond, 2002; Prahalad and Hart, 2002; Prahalad, 2005), it has been argued that these businesses cannot serve as a panacea for global poverty. One distinct criticism of the predominant $\mathrm{BoP}$ vision is that consumption as a means of poverty alleviation is simply a flawed strategy. The best way to help the poor, critics argue, 
SAJGBR

2,1

46 is by employing them and/or buying from them, rather than selling to them to raise their incomes (Karnani, 2007). Walsh et al. (2005) argued that scholars who believe that MNC investments lead to poverty elimination (Prahalad and Hart, 2002; London and Hart, 2004; Prahalad, 2005), need to address the mechanisms through which those investments would achieve these goals. They refer to one of Prahalad's (2005) examples of the advantages of BoP consumer businesses, the Casas Bahia story[1] and question, "How will buying a television set or a new set of furniture on easy credit [...] lift a family out of poverty?" (Walsh et al., 2005, p. 485). Jaiswal (2008) also argues that BoP businesses should sell proper products to the poor. He argues that many of the products described in the literature are actually harming their well-being; however, at the same time products that increase the poor's ability to produce, communicate, learn and lead healthier lives should be focussed upon.

Davidson (2009) expresses concern that focussing on the BoP from a purely economic vantage point is unwise and could easily frustrate BoP businesses that did not adopt a corporate social responsibility (CSR) perspective. He argues that firms ought to view the poor as stakeholders and shun profit maximization as an ultimate goal. Hahn (2009) also tries to establish BoP as stakeholders. He argues that while it is unclear whether BoP businesses do in fact alleviate poverty, the involvement of MNCs, either directly or indirectly, in the lives of members of the BoP, implies that the poor are their stakeholders or corporate citizens. It is true that in developing countries, MNCs have more wealth and ability to relieve poverty than the host nation. Morally responsible MNCs must therefore consider how they are impacting the poor (their stakeholders) and consider ways in which they are ideally suited to make a positive impact to their overall well-being. Despite these contributions, BoP scholarship still lacks focus in determining which types of business create value for the poor.

\section{Highlighting BoP producer businesses}

The BoP Protocol 2.0 (Simanis and Hart, 2008) has been offered as a superior alternative to previous models. The approach calls for treating the $\mathrm{BoP}$ as a business partner and establishing deep dialogue through close face-to-face relationships, i.e. creating business models through embedded innovation. However, many of the processes proposed by that model can be enacted and still fail to alleviate poverty if their goal is slowly "building the market base" (Simanis and Hart, 2008) with the ultimate objective of selling goods and services with the poor but still to the poor. While such an approach is a step in the right direction, we believe it should be broadened to include all goods that are created or built at the BoP.

London et al. (2010) and Rangan et al. (2007) distinguished between the BoP consumer and BoP producer approaches. BoP consumer businesses are much in line with Prahalad and Hart's (2002) original vision of selling suitable products to the poor. BoP producer businesses, on the other hand, involve producing at the BoP to access more munificent markets and then sell those products. Both strategies connect the poor with more developed markets, though in different ways. Additionally, a hybrid model similar to BoP Protocol 2.0 - can combine the two approaches (London et al., 2010). London et al. (2010) highlighted lack of skill, knowledge, technology and access to the broader markets as the chief limits to the poor in escaping intense poverty. They suggested that businesses partnering with the poor could provide critical factors, like market access, which could in turn reduce poverty. We argue below that BoP producer businesses essentially have a greater capability for accomplishing this. 
Sen (1985) had argued that measures of human well-being should capture the ability to achieve rather than simply measuring current economic utility. Ansari et al. (2012) used Sen's definition of poverty as a lack of capability or empowerment to achieve for one's self and argued that some of the BoP businesses (that were lauded in the literature) actually destroyed these capabilities. Hence, they suggest that BoP businesses should be evaluated to the extent to which they either expand self-capability and empowerment or destroy them. BoP producer businesses not only allow the poor to consume more by raising their incomes or increasing their choices. They also raise the dignity of the poor and their ability to achieve by facilitating outcomes that the poor cannot achieve for themselves, thereby conforming to Sen's (1985) understanding of human "capability" that is defined as having the power to choose from a variety of feasible outcomes. MNCs can play a major role here. For instance, they can transfer knowledge and capabilities from their organization to BoP individuals and societies. They can also provide and promote "bridging social capital," by placing the poor in organizations in connection with peripheral social ties rich in information and unique resources (Ansari et al., 2012).

Based upon review of the BoP literature, despite its nascent status, we believe that it is lacking in at least two areas. First, while there are several studies that have discussed poverty alleviation, these do not provide clear mechanisms for showing which BoP businesses can actually achieve this. One notable exception is Ramachandran et al.'s (2012) recent work that offered some suggestions in this regards. We argue that scholars, across disciplines, need to examine the economic and cultural outcomes of BoP businesses on the poor to be able to discuss mechanisms for alleviating poverty, in order to provide a more holistic understanding of $\mathrm{BoP}$ ventures. Second, of the two categories of BoP businesses, there are very few papers that have examined producer models of BoP businesses. We believe that there is much to be gained from focussing upon a producer approach that appears to be more capable of helping alleviate poverty and developing human capability.

Ramachandran et al. (2012) reasoned that connecting BoP producers with larger firms would benefit their small entrepreneurial businesses and consequently help those poor communities overcome some of the market constraints and capability limitations they face. They categorized positive poverty alleviation outcomes of these businesses into three spheres: access to product and factor markets; access to knowledge-rich ecosystems that provide knowledge and innovation skills; and access to well established organizations. We use these outcomes to develop propositions with the purpose of highlighting the advantage of $\mathrm{BoP}$ producer businesses in creating value.

a. Accessing more munificent product and factor markets. Wages for many jobs in the service sector are tightly linked to the incomes in technology dependent industries (Baumol, 1967; Heilbrun, 2003). This means that the price of technology-independent services in growing and developed economies can be dramatically higher than the same services on offer in undeveloped economies. Income from such services rises with the level of technology and the productivity in other sectors. Unless technology dependent sectors are also growing, wages in the technology-independent parts of the service sector tend to stay low. Aykut and Sayek (2007) show that if FDI is directed at the manufacturing sector, economic growth will follow. As increased investment in manufacturing improves productivity, consumer-based businesses operating in the service sector will become more profitable. For example, China's manufacturing sector 
SAJGBR

2,1

48 is a much larger percentage of its economy than India's (International Monetary Fund, 2011) and the Chinese economy has grown more rapidly. Similarly, Ramaswamy and Agrawal (2012) concluded that the, "[...] service-sector is an unlikely destination for millions of low skilled job seekers. India needs to focus on the manufacturing sector to provide large scale employment" (p. 1). This analysis applies to the $\mathrm{BoP}$ in other emerging and developing economies, thus casting doubts on the exclusive use of the BoP consumer model.

The inability of technology-independent service-sector growth is closely related to the Baumol effect, which describes an increase of wages in jobs, like services, without any improvement in productivity (Baumol, 1967; Heilbrun, 2003). This increase in wages is caused by the need to compete for employees in sectors or jobs that did enjoy productivity increases. Technological advances in those occupations lead to higher wages in those sectors causing an increased demand for technology-independent services due to more affluent patrons. Baumol and Bowen (1965) pointed out that the productivity of musicians playing a composition by Beethoven has not increased since the early nineteenth century, whereas their wages have increased, in general, through productivity gains. Similarly, since service-based BoP consumer businesses only access local technology-poor markets, a reverse Baumol effect takes place. This is why we observe that most services, ranging from housekeeping to attorneys and healthcare, cost much less at the BoP.

Whereas Baumol was concerned with the high cost of services and the arts in urban centers like New York City, the low cost of services at the BoP can jeopardize BoP consumer businesses' poverty alleviation mechanisms. The BoP consumer logic calls for serving the needs of the poor by utilizing the poor to sell and distribute products (Viswanathan et al., 2011) and hence, it is largely service-driven. However, the Baumol effect shows that service sector wage growth is actually caused by increases in technology in the surrounding environment. Since goods are sold by MNCs, through the poor to the poor, more technologically developed markets, which are accessed by BoP producer efforts, are never tapped. It is intuitive, then, that wages in BoP consumer businesses, will likely, remain low so long as productivity levels of their customers also remain low. Therefore, consumer businesses alone cannot have the power to lift large segments of the population from poverty.

From a BoP producer perspective, Ramachandran et al. (2012) identified access to markets as one area where BoP producer businesses aid the poor by allowing them to create goods at the $\mathrm{BoP}$ and then transfer them to more munificent markets. Dastkar, a society of crafts and craftspeople in India, is a BoP producer business that connects their producers, mostly women, with a wider market. Dastkar designs, work with the poor to develop, markets and sells competitive products to a more munificent market. Craftspeople are connected to these markets through Dastkar's bazaars and exhibitions in various Indian cities. Additionally, Dastkar has recently acquired an export license, enabling it to reach an alternative international market. This access results in raising income levels by linking the BoP with higher income consumers. A study by Dastkar showed that by integrating BoP production with more technologically advanced markets, a channel for rapid increases in incomes becomes available for BoP producers. This logic leads us to propose:

P1a. BoP producer businesses create value for the poor that $\mathrm{BoP}$ consumer businesses cannot by accessing more technologically developed, munificent product markets for them. 
In addition to providing access to markets for products, BoP producer businesses also provide the poor with access to factor markets and organizations that directly link them with physical capital (Ramachandran et al., 2012). The level of capital-intensity per worker, is a key predictor of output per worker, their income levels and even national productivity (De Long, 1991; Jorgenson and Vu, 2005). De Long (1991) found that investment in equipment was highly correlated with economic growth of various countries and that the key difference between East Asian nations that grew and Latin American nations (with similar governments) that did not grow was the level of investment in machinery. Their findings also indicate that high rates in equipment investment accounts for the preponderance of Japan's post-Second World War growth performance. Jorgenson and Vu's (2005) analysis found that developing Asia accounted for 60 per cent of the world economic growth between 1989 and 1995 and 40 per cent between 1995 and 2003, with China responsible for half of this. Investment in tangible assets, including IT equipment and software, was the leading cause of this impressive growth. Additionally, 80 per cent of world economic growth was caused by investment in inputs rather than consumer purchases (Jorgenson and $\mathrm{Vu}, 2005$ ).

BoP producer businesses transfer more productive capital like factories, machinery and raw materials from firms to the global poor through FDI (than BoP consumer businesses are able to do so), thus allowing the poor to be more productive. Rather than sewing clothes or planting crops by hand, the poor can join capital-intense organizations. In addition, BoP entrepreneurs, with connections to investment capital serving as loans, can expand their own businesses, further investing in equipment and other capital requirements. An injection of well-allocated capital into an economy's productive sector can significantly increase output and raise the potential for sustainable economic growth. BoP consumer businesses, on the other hand, introduce little productive capital to the BoP, because their business model merely leverages the poor's existing capital and capabilities (e.g. Project Shakti discussed previously). This leads us to propose:

P1b. BoP producer businesses create more value for the poor than BoP consumer businesses by improving their access to the factors of production, which improves the capital to labor ratio and raises income levels.

b. Transfer of productive knowledge and capabilities. FDI (such as BoP producer businesses) not only impacts economic growth and development through access to factors and markets, but through increases in productivity due to an increase in technology (Keller, 1996; Mody and Murshid, 2005). Firms specialize in the creation of productive knowledge (Grant, 1996) and the idiosyncratic capabilities that help perform firm-specific tasks efficiently (Nelson and Winter, 1982). Internationalization leverages these advantages to markets where they do not yet exist (Kogut and Zander, 1993).

Lall and Pietrobelli (2002) describe how South Korea strategically attracted foreign technologies to record impressive economic growth. In essence, South Korea realized that they had a productive knowledge and capability deficit and, thus, implemented investment policies that attracted MNCs with competencies (such as an understanding of a technology, a means of producing, an organizational skill or a business model) to locate there (Lall and Pietrobelli, 2002). Alfaro et al. (2009) found that countries with stable financial markets could benefit from FDI primarily through the mechanism of technology gains (total factor productivity). Similarly, Aykut and Sayek (2007) 
SAJGBR

2,1

\section{0}

argued that these productivity gains are only felt when manufacturing firms become the largest part of FDI because there is much more technology associated with this sector.

The introduction of knowledge-rich organizations and ecosystems (Ramachandran et al., 2012) can allow BoP environments to produce new goods and services, as BoP producer businesses provide the poor with knowledge and expertise that they currently lack. Romer (1993) argues that some "nations are poor because their citizens do not have access to the ideas that are used in industrial nations to generate economic value" (p. 543). By incorporating individuals into productive processes and exposing them to new ideas, productive firms help stimulate economic growth. New ideas require learning because they involve activities that may initially be difficult to perform and understand. MNCs can help facilitate this learning.

$\mathrm{BoP}$ consumer businesses are not as technologically sophisticated as $\mathrm{BoP}$ producer businesses. Entrepreneurs are already distributing various products and services (Banerjee and Duflo, 2007) and BoP consumer businesses simply utilize these competencies instead of creating new ones. Creating products is a far more organizationally complex and knowledge intense task than distributing them and its benefits to a society are far reaching (Lall and Pietrobelli, 2002). As part of Operation Flood, Milma, a dairy cooperative in Kerala (India), has used artificial insemination to completely replace the local farmers' dairy cattle population over the last 30 years with a newly developed breed. This knowledge was imported through an alliance with a Swiss development agency and the Indian Government, and a study reported that this resulting in an annual increase in milk production by the average Kerala dairy cow by a factor of ten. This lead us to the following proposition:

P2a. BoP producer businesses create more value for the poor than $\mathrm{BoP}$ consumer businesses by transferring more productive technology.

In addition to acquiring existing technology, BoP producer businesses can also improve a society's innovative capability. Long-term economic benefits arise from enhancing the innovation capability of business ecosystems (Reddy and Zhao, 1990; Lall, 1992). Unfortunately, knowledge, capabilities and other rent collecting characteristics are tacit in nature and therefore must be slowly learned rather than instantly transferred. This learning will likely be slower in developing countries that are resource-scarce and have few capabilities (Keller, 1996). Schumpeter (1934) described innovation as being essential to economic growth. From this perspective, economic growth is achieved by knowledge manipulation and recombination. The ability to recombine resources is a valuable firm and national capability (Schumpeter, 1934). Unfortunately, developing countries with large BoP populations lack the resources (physical, organizational or otherwise) to learn from and recombine. Hence they are likely unable to innovate. Countries that have achieved success have merged existing resources into more valuable combinations giving themselves more resources to draw from resulting in better resource combinations. The infusion of manufacturing into China has doubled its share of patents as a percentage of world patents in the last five years. For example, China has made significant technological contributions to both the solar and wind power industries. The manufacturing resources that came to China in the 1980s and 1990s are just beginning to generate an innovation dividend. Such resources can be adapted to their environment in order to achieve custom solutions. 
In fact, because of the importance of idiosyncratic and related knowledge in the learning and innovation processes (Cohen and Levinthal, 1990), such innovations could likely prove highly tailored and valuable to the BoP than those developed outside a BoP context (London and Hart, 2004). BoP producer businesses benefit their target markets by providing them with exposure to technology and organizations, which are building blocks for future innovation. Thus, we propose the following:

\section{The global poor}

P2b. BoP producer businesses create more value for the poor than BoP consumer businesses through the enhancement of their host's innovative capability.

c. Access to productive organizations. Information deficiencies are pronounced in underdeveloped economies. Geertz (1978) has argued that, "The level of ignorance about everything from product quality and going prices to market possibilities and production costs is very high" (p. 29). In developing countries profitable opportunities for specialization are difficult for the poor to envision because potential markets and business partners are never even encountered due to institutional gaps (Webb et al., 2010). Hence, entrepreneurial opportunity cannot be perceived (Kirzner, 1978), and the poor become subsistence "entrepreneurs," operating in the institutional context that they know, dividing their time among various occupations (Banerjee and Duflo, 2007). MNCs can help solve this problem by reducing high transaction costs caused by bounded rationality through virtue of their presence.

While many neoclassical institutional economists (North, 1987; etc.) advocate the reduction of high transaction costs in underdeveloped countries through the adoption of better property rights and national governance, it is unclear how these changes might improve the knowledge of economic opportunities available to the poor. However, private firms can reduce transaction costs (Williamson, 1975) and help overcome ignorance of opportunities. Moran and Ghoshal (1999), explain how organizations aid in the process of economic development.

"By permitting individuals and groups to enter into voluntary exchanges that benefit the organization but that benefit themselves only indirectly, organizations can open up and make accessible to their members a much broader range of resource deployments" "bridg[ing] missing markets" (Moran and Ghoshal, 1999, p. 402).

Access to organizations is one of the three key factors that BoP producer businesses provide the poor (Ramachandran et al., 2012) helping them specialize in interdependent tasks. As economies have developed and increasingly specialized in production, the advantages of specialization have been borne out repeatedly, recently in places like China and the Asian Tigers.

MNCs offer the poor a chance to band together in cooperatively in organizations to create output that would have been unimaginable without them. To modify Smith's (1986) famous example of the pins: a woman working at home, dividing her attention among various economic activities, may be able to make one shirt per month to sell without the aid of organizations that can reduce transaction costs, but with these institutions that same woman can join a group of 100 women producing 1,000 shirts per day, meaning her marginal product would be 2,000-3,000 shirts per month, rather than the one. When fairly compensated for her labor, such specialization would significantly increase the woman's income and help her escape poverty.

Milma, the previously mentioned dairy farm cooperative in India, has greatly reduced information asymmetries, transaction costs and the inability of dairy farmers 
SAJGBR

2,1

52 to take advantage of economies of scale since its foundation in the early 1980s. Before Milma, farmers could only afford to milk a few cows by hand. They merely consumed their cows' milk and bartered the remainder with neighbors before it spoiled. It has been reported that the farmers combined their resources through the government initiated cooperative to buy refrigerated milk trucks and cooling tanks, pasteurizing equipment and packaging machinery that allowed them to dramatically increase production and inundate India's cities with milk. Of course, no single Indian rural dairy farmer could afford their own cooling trucks and therefore could not specialize enough to produce large quantities of milk. BoP consumer businesses also enhance specialization by employing the poor as full time salespeople due to the transaction costs that were reduced in the production process. Hence a blanket statement in regards to the superiority of $\mathrm{BoP}$ producer firms cannot be made here. However, large firms operating at the $\mathrm{BoP}$ have the advantage of reducing transaction costs in ways that smaller go-it-alone businesses cannot, providing a unique role for large MNCs with vast resources to make a meaningful impact. This leads us to the following proposition:

P3. Large BoP businesses create more value for the poor than small businesses at the BoP by pooling productive efforts cooperatively to allow specialization.

\section{Conclusions}

Prahalad's initial thesis was compelling, but theoretically weak (Walsh et al., 2005) and in practice, BoP failures have been common (Simanis and Hart, 2008). Given the spotty track record of BoP businesses, there should be an emphasis on strengthening theoretical and empirical work leading to some assurance that BoP businesses are in fact helping the poor. Following Karnani's (2007) call to view the poor as producers, scholars have begun to examine the BoP producer model (London et al., 2010; Ramachandran et al., 2012). We have also taken a step in this direction. We hope that the propositions developed here, related to the benefits suggested by Ramachandran et al. (2012) advance research in: BoP producer ventures and the effects of BoP businesses on the poor. Although it could be difficult, each of these propositions is empirically testable. Perhaps survey measures related to the perceived value of different types of $\mathrm{BoP}$ business can be developed to test the above propositions. We believe that such a research agenda would decrease the predominance of the BoP consumer model found in much of the current research.

At the very least, we hope that our propositions can broaden research so that it increasingly examines effective poverty alleviation strategies and does not myopically concentrate on the financial performance of $\mathrm{BoP}$ ventures. If the efforts of many managers are predicated on the notion that their efforts are helping the poor, the focus of BoP research should broaden to include whether these businesses do in fact have a positive impact on them (Ansari et al., 2012).

In response to the criticism that selling to the poor does not really benefit them (Karnani, 2007; Simanis and Hart, 2008; etc.), some of the recent literature has examined cases where the product offered to the poor has poverty alleviating characteristics. In many of these cases, embedded innovation has created products tailored directly to the poor's needs. Allianz, because it is required by the Indian Government to reach rural markets, has offered life and disaster insurance to the poor (Schrader et al., 2012). Grameen Phone, in Bangladesh (Simanis and Hart, 2009; Schrader et al., 2012; etc.), has developed a time share village telephone business 
model for use on a pay-per-minute basis. $P \& G$ has delivered clean drinking water solutions, the PuR Water Filtering System, to several BoP contexts including India and Pakistan. Magazine Luiza, in Brazil (Nakata and Weidner, 2012), has arranged for the poor in the steamy rainforests of Brazil to buy refrigerators and other white goods collectively on credits. It is very difficult to be critical of businesses that provide needed products to the $\mathrm{BoP}$ and we do not wish to undermine these endeavors. Such product introductions give the poor better options in allocating their $\$ 1,500$ or less. However, for the most part, they are not allowing them new access to markets, knowledge and organizations.

Not only can BoP producer businesses lift the poor's welfare, but also their ability to achieve for themselves. Much like Ansari et al. (2012), we also wish to make mention of Sen's (1985) notion of human capabilities. Whereas Ansari et al. (2012) focussed on how $\mathrm{BoP}$ businesses can impact social capital and ultimately human capabilities, this paper implies additional ways that $\mathrm{BoP}$ businesses can enhance them. BoP businesses, especially BoP producer businesses enrich the capabilities of the poor by increasing the social contribution of their labor hours, enhancing the extent of their knowledge and skill-base, improving their ability to innovate and building indigenous institutions and organizations which aid in developing their social capital. All of these mechanisms, enhance the choices and opportunities - capabilities according to Sen - that the poor have. In fact, this capability enhancement should be a primary focus of BoP producer businesses as a poverty alleviation mechanism. Governments and policymakers should also view human capabilities as such and find ways to attract, develop and assist local businesses. As countries improve the knowledge and opportunities of its citizens, indices like the Human Development Index score (a country level measure based on Sen's notion of capabilities and developed by the United Nations) should also improve (UNDP, 1999).

The research presented here has limitations. We have not based our propositions on in-depth empirical findings about BoP businesses but rather on a variety of economic theories. Still, we hope that this paper will serve as a guide to future research in the following ways. First, the ideas espoused here will need to be empirically verified by examining the poverty alleviation effects of $\mathrm{BoP}$ producer businesses against BoP consumer businesses. This will likely involve expanded case studies in conjunction with some theoretical inference given that firms' benefits to societies are very difficult to capture.

It might also involve, as mentioned above, surveys of the perceived value that BoP businesses add to their communities. The value created for the poor by a particular BoP business is a difficult construct to capture; however, key actors' perceptions of outcomes for a large cross-section of firms over time could help generate clarity in this matter. Such perceived value, stemming from each of our individual propositions can probably be tested in survey form and combined with data regarding the business's attributes (e.g. firm size or coding BoP businesses as predominantly producer or consumer). Similarly, we believe that future research on business models for the BoP should attempt to articulate the value it will create for the BoP community in which it is located. Such an examination of the outcome on the poor in a proposed business model or innovation process is the exception rather than the rule in the BoP literature. Finally, scholars should further examine how firms can overcome sometimes hostile political and institutional forces, at the BoP. While such research has been undertaken in the past (Cuervo-Cazurra, 2006; etc.), more needs to be done specifically for creating productive operations in $\mathrm{BoP}$ environments. 
SAJGBR

2,1

54
The perspective that we have adopted in this paper raises several questions. First, have we broadened the definition of a $\mathrm{BoP}$ business with our focus on employing the poor as producers rather than consumers (Prahalad and Hart, 2002; etc.) or business partners (Simanis and Hart, 2008)? London (2007) states that BoP producer initiatives do not include those businesses, "based solely on having employment relationships with those at the base of the pyramid" (p. 4). We see no reason for this distinction between firms that do and do not design their business model together with the poor, however. If a business is connecting products created at the $\mathrm{BoP}$ with non-BoP markets, it is serving the BoP. Just because most of the BoP research within the Strategic Management field to date does not focus on this scenario, it should not be excluded from discussion. The businesses outlined in London et al. (2010) that sell goods native to the $\mathrm{BoP}$ are certainly exemplary BoP businesses; however, more traditional manufactured goods can also be legitimate BoP products, so long as they connect $\mathrm{BoP}$ actors with non-BoP actors in economically meaningful ways. The Indian textile company, Arvind Mills, for instance, now the world's fourth largest producer and exporter of denim, was used as a successful example of a BoP business in the original BoP vision for poverty alleviation (Prahalad and Hart, 2002). While such businesses may initially serve the poor by "merely" employing them as unskilled labor, this will not be the permanent station of the poor workers.

Second, many of the developing economies have risky institutional environments. Initially, the BoP producer business model will prove challenging in countries where regulative institutions are weak, cultures are dissimilar and human capital is relatively low. There, MNCs will have to realize that operating losses are a strong initial possibility in their efforts to help raise living standards at the BoP. Investing in a BoP producer strategy involves more fixed costs and exposes the firm to more location specific risk than investing in a BoP consumer strategy. Such arises from exposure to political corruption (Cuervo-Cazurra, 2006) and liability of foreignness (Kostova and Zaheer, 1999). It may take several years of operating at a loss for firms to be able to constructively shape and adapt to their environments enough to be profitable. As with all BoP endeavors, patient capital will be needed (Simanis and Hart, 2008) as initial uncertainties are slowly navigated. However, as the effects of the presence of these productive businesses are felt, a much more positive operating environment can be enacted in places with lower-cost labor. Businesses that are there first will enjoy first-mover advantages when the economy begins to develop. They will likely benefit from environmental familiarity, brand recognition and loyalty as a consumption market develops and government favor.

Finally, our perspective raises the issue of whether our planet can sustain more production? This is indeed one of the toughest challenges for BoP producer advocates. Hahn (2009) argues that by increasing incomes at the BoP, birthrates will decrease, lessening some of the strain on the environment. Despite this possible solution to the criticism, we reject the premise of this question insofar as those who ask it wish to keep the poor producing and consuming far less because our planet cannot sustain their rise from poverty. Median Americans consume nearly 100 times as much as the average person at the BoP. Solutions to problems of sustainability should not begin at the BoP. This is a question for ecologists and environmental economists, but sustainability research should find alternatives to solutions that might jeopardize economic growth in the developing countries. The picture Banerjee and Duflo (2007) have painted about the challenges that the poor face, in our experiences and observations, is very accurate and should be given priority over many other concerns. 
Despite the limitations and questions mentioned above, the value in shifting to a BoP producer research program is difficult to understate. BoP producer businesses can potentially create enormous economic value and enhance the capabilities of the poor, empowering them to rise above a subsistence lifestyle. MNCs and other BoP producer businesses provide the poor with access to markets, knowledge and organizations (Ramachandran et al., 2012), which are the economic fundamentals that they currently lack. Simply selling to the poor cannot address poverty nearly as effectively.

\section{The global poor}

\section{Note}

1. Casas Bahias is a highly successful retailer in Brazil, which sells furniture, home appliances and electronics to low-income customers by providing them with a line of credit. This allows these consumers to make purchases valued at several weeks or months of their personal income by spreading out their payment over 4-12 months (Prahalad, 2005).

\section{References}

Alfaro, L., Kalemli-Ozcan, S and Sayek, S. (2009), "FDI, productivity and financial development", World Economy, Vol. 32 No. 1, pp. 111-35.

Anderson, J. and Markides, C. (2007), "Strategic innovation at the base of the economic pyramid", MIT Sloan Management Review, Vol. 49 No. 1, pp. 83-8.

Ansari, S.S., Munir, K. and Gregg, T. (2012), "Impact at the bottom of the pyramid: the role of social capital in capability development and community empowerment", Journal of Management Studies, Vol. 49 No. 2.

Aykut, D. and Sayek, S. (2007), "The role of the sectoral composition of foreign direct investment on growth", in Piscitello, L. and Santangelo, G. (Eds), Do Multinationals Feed Local Development and Growth, Elseiver, Boston, MA, pp. 35-62.

Banerjee, A.V. and Duflo, E. (2007), "The economic lives of the poor", Journal of Economic Perspectives, Vol. 21 No. 1, pp. 141-67.

Baumol, W.J. (1967), "Macroeconomics of unbalanced growth: the anatomy of urban crisis", American Economic Review, Vol. 57 No. 3, pp. 415-26.

Baumol, W.J. and Bowen, W.G. (1965), "On the performing arts: the anatomy of their economic problems”, American Economic Review, Vol. 55 Nos 1/2, pp. 495-502.

Cohen, W.M. and Levinthal, D.A. (1990), “Absorptive capacity: a new perspective on learning and innovation”, Administrative Science Quarterly, Vol. 35, pp. 128-52.

Cuervo-Cazurra, A. (2006), "Who cares about corruption?", Journal of International Business Studies, Vol. 37 No. 6, pp. 807-22.

Davidson, K. (2009), "Ethical concerns at the bottom of the pyramid: where CSR meets BOP", Journal of International Business Ethics, Vol. 2 No. 1, pp. 22-32.

De Long, J. (1991), "Productivity and machinery investment: a long run look 1870-1970", Working Paper No. 3903, National Bureau of Economic Research.

Geertz, C. (1978), "The bazaar economy: information and search in peasant marketing", American Economic Review, Vol. 68 No. 2, pp. 28-32.

Grant, R.M. (1996), “Toward a knowledge-based theory of the firm”, Strategic Management Journal, Vol. 17, pp. 109-22.

Hahn, R. (2009), "The ethical rational of business for the poor - integrating the concepts of bottom of the pyramid sustainable development, and corporate citizenship", Journal of Business Ethics, Vol. 84, pp. 313-24.

Heilbrun, J. (2003), "Baumol's cost disease", in Towse. R. (Ed.), A Handbook of Cultural Economics, Edward Elgar Publishers, Northhampton, MA. 
SAJGBR

2,1
International Monetary Fund (2011), "World economic and financial surveys: world economic outlook database", available at: www.imf.org/external/pubs/ft/weo/2011/01/weodata/ index.aspx

Jaiswal, A.K. (2008), "The fortune at the bottom or the middle of the pyramid", Innovations, Winter, pp. 85-100.

Jorgenson, D.W. and $\mathrm{Vu}, \mathrm{K}$. (2005), "Information technology and the world economy", Scandinavian Journal of Economics, Vol. 107 No. 4, pp. 631-50.

Karnani, A. (2007), "The mirage of marketing to the bottom of the pyramid", California Management Review, Vol. 49 No. 4, p. 90.

Keller, W. (1996), "Absorptive capacity: on the creation and acquisition of technology in development", Journal of Development Economics, Vol. 49 No. 1, pp. 199-227.

Kirzner, I. (1978), Competition and Entrepreneurship, University of Chicago press, Chicago, IL.

Kogut, B and Zander, U. (1993), "Knowledge of the firm and the evolutionary theory of the multinational corporation", Journal of International Business Studies, Vol. 24, pp. 625-45.

Kostova, T. and Zaheer, S. (1999), "Organizational legitimacy under conditions of complexity: the case of the multinational enterprise", Academy of Management Review, Vol. 24 No. 1, pp. 64-81.

Lall, S. (1992), "Technological capabilities and industrialization", World Development, Vol. 20 No. 2, pp. 165-86.

Lall, S. and Pietrobelli, C. (2002), Failing to Compete: Technology Development and Technology Systems in Africa, Edward Elgar Publishers.

London, T. (2007), "The base-of-the-pyramid perspective: a new approach to poverty alleviation", working paper, William Davidson Institute, M. Ross School of Business, University of Michigan.

London, T. and Hart, S.L. (2004), "Reinventing strategies for emerging markets: beyond the transnational model", Journal of International Business Studies, Vol. 35 No. 5 , pp. 350-70.

London, T., Anupindi, R. and Sheth, S. (2010), "Creating mutual value: lessons learned from ventures serving base of the pyramid producers", Journal of Business Research, Vol. 63 No. 6, pp. 582-94.

Mody, A. and Murshid, A.P. (2005), "Growing up with capital flows", Journal of International Economics, Vol. 65 No. 1, pp. 249-66.

Moran, P. and Ghoshal, S. (1999), "Markets, firms, and the process of economic development", Academy of Management Review, Vol. 24 No. 3, pp. 390-412.

Nakata, C. and Weidner, K. (2012), "Enhancing new product adoption at the base of the pyramid: a contextualized model", Journal of Product Innovation Management, Vol. 29 No. 1, pp. 21-32.

Nelson, R.R. and Winter, S.G. (1982), An Evolutionary Theory of Economic Change, Harvard University Press, Cambridge.

North, D.C. (1987), "Institutions, transaction costs and economic growth", Economic Inquiry, Vol. 25 No. 3, pp. 419-28.

Pitta, D.A., Guesalaga, R. and Marshall, P. (2008), "The quest for the fortune at the bottom of the pyramid: potential and challenges", Journal of Consumer Marketing, Vol. 25 No. 7 , pp. 393-401.

Prahalad, C.K. (2005), The Fortune at the Bottom of the Pyramid: Eradicating Poverty through Profits, Wharton School publishing, NJ. 
Prahalad, C.K. and Hammond, A. (2002), "Serving the world's poor, profitably", Harvard Business Review, Vol. 80 No. 9, pp. 48-59.

Prahalad, C.K. and Hart, S.L. (2002), "The fortune at the bottom of the pyramid", Strategy + Business, Vol. 26, pp. 54-67.

Ramachandran, J., Pant, A. and Pani, S.K. (2012), "Building the bop producer ecosystem: the evolving engagement of Fabindia with Indian handloom artisans", Journal of Product Innovation Management, Vol. 29 No. 1, pp. 33-51.

Ramaswamy, K. and Agrawal, T. (2012), "Services-led growth, employment and job quality: a study of manufacturing and service-sector in urban India", Indira Gandhi Institute of Development Research, Mumbai.

Rangan, V.K., Sehgal, D. and Rajan, R. (2007), "The complex business of serving the poor: insights from Unilever's project Shakti in India”, in Rangan, V.K., Quelch, J.A., Herrero, G. and Barton, B. (Eds), Business Solutions for the Global poor: Creating Social and Economic Value, Jossey-Bass, San Francisco, CA, pp. 144-54.

Reddy, N.M. and Zhao, L. (1990), "International technology transfer: a review", Research Policy, Vol. 19 No. 4, pp. 285-307.

Romer, P. (1993), "Idea gaps and object gaps in economic development", Journal of Monetary Economics, Vol. 32 No. 3, pp. 543-73.

Schrader, C., Freimann, J. and Seuring, S. (2012), "Business strategy at the base of the pyramid", Business Strategy and the Environment, Vol. 21 No. 5, pp. 281-98.

Schumpeter, J.A. (1934), The Theory of Economic Development, Harvard University Press, Cambridge.

Sen, A.K. (1985), Commodities and Capabilities, Oxford University Press, Oxford.

Simanis, E. and Hart, S. (2008), The Base of the Pyramid Protocol: Toward Next Generation Bop Strategy, Cornell University.

Simanis, E. and Hart, S. (2009), "Innovation from the inside out", MIT Sloan Management Review, Vol. 50 No. 4, pp. 78-86.

Smith, A. (1986), The Wealth of Nations, Penguin Classics, New York, NY.

Subrahmanyan, S. and Gomez-Arias, J.T. (2008), "Integrated approach to understanding consumer behavior at bottom of pyramid", Journal of Consumer Marketing, Vol. 25 No. 7 , pp. $402-12$.

Unilever (2005), "India: creating rural entrepreneurs", available at: www.unilever.com/ sustainability/casestudies/economic-development/creating-rural-entrepreneurs.aspx

UNDP (1999), Human Development Report 1999, Oxford University Press, New York, NY.

Viswanathan, M., Yassine, A. and Clarke, A. (2011), "Sustainable product and market development for subsistence marketplaces: creating educational initiatives in radically different contexts", Journal of Product Innovation Management, Vol. 28 No. 4, pp. 558-69.

Walsh, J.P., Kress, J.C. and Beyerchen, K. (2005), "Book review essay: promises and perils at the bottom of the pyramid", Administrative Science Quarterly, Vol. 50 No. 3, pp. 473-82.

Webb, J.W., Kistruck, G.M., Ireland, R.D. and Ketchen, D.J. (2010), "The entrepreneurship process in base of the pyramid markets: the case of multinational enterprise/ nongovernment organization alliances", Entrepreneurship: Theory \& Practice, Vol. 34 No. 3, pp. 555-81.

Williamson, O.E. (1975), Markets and Hierarchies: A Study in the Economics of Internal Organization, Free Press, New York, NY. 
SAJGBR

2,1

58

\section{About the authors}

Adam Smith is a Strategic Management PhD student at Old Dominion University, USA. He has an MA in Applied Economics from Western Kentucky University, USA. His research interests include base of the pyramid issues, entrepreneurship, and innovation. Adam Smith is the corresponding author and can be contacted at: a8smith@odu.edu

Amir Pezeshkan is a $\mathrm{PhD}$ student in Strategic Management and International Business at Old Dominion University, USA. He has an MBA in Strategic Management from MUT University of Tehran, Iran. His research interests include base of the pyramid, international strategic alliances, and entrepreneurship.

To purchase reprints of this article please e-mail: reprints@emeraldinsight.com Or visit our web site for further details: www.emeraldinsight.com/reprints 